\title{
Instrumental Motivation of English Online Learning During Pandemic Covid-19
}

\author{
I Gusti Ayu Vina Widiadnya Putri, Ida Bagus Gde Nova Winarta \\ Faculty of Foreign Languages, Mahasaraswati Denpasar University. \\ miss.vina@unmas.ac.id
}

\begin{abstract}
This study aims to identify and analysed the Instrumental Motivation of English online learning during pandemic covid-19. Teachers and learners must be consistent in carrying out learning in special conditions nowadays. A teacher has very important role in fostering student motivation to take part in online learning, so the failures in the process of transferring knowledge to students can be minimized. This research is quantitative and descriptive qualitative study to examine Instrumental motivation in online learning during pandemic covid-19. The random sampling was used in this study. The questionnaire was used as an instrument in this study. The questionnaire consists of 12 questions as a test of instrumental motivation which is divided into three different types of questions such as: academic motivation, individual motivation and social motivation. The responses obtained from the participants were classified into five categories according to Gardner's Attitude and Motivation (Jefiza, 2017), such as; strongly agree, agree, doubt, disagree and strongly disagree. It was found that the motivation of students in online learning conducted in class was to finish on time. The total mean of academic aspect is 3.61 at the moderate level. Meanwhile, for the personal aspect, it was found that the value for the total mean of the personal aspect was 3.69 at a high level, and the mean of social aspects on instrumental motivation was 3.89 at a high level. It can be shown that, the students still have high motivation in taking online learning even during the pandemic covid-19.

Keyword : Instumental, Motivation, Online Learning.
\end{abstract}

\section{Introduction}

The covid-19 virus outbreak is a pandemic that cannot be underestimated. This pandemic has claimed hundreds of human lives every day. This fear arose when the Covid-19 virus outbreak began to enter Indonesia in early 2019. Instantly, all aspects of people's life changed completely. Various government efforts to break the chain of the spread of Covid-19 were carried out. Starting from closing all activities outside the home, to start new normal. Of course, what is of concern to the government is in the education sector. Education in Indonesia, which has been based offline and face-to-face, has changed to an online learning. The Education sector has begun to close all school activities, lectures, practices that gather many people in one place. For this reason, educators, teachers, instructors have started to implement online learning / online classes, including at Faculty of Foreign Languages, Mahasaraswati Denpasar University. (Maulidina \& Bhakti, 2020) stated that the government enforced a social distancing policy or known as physical distance, schools 
decided to study distance but what was feared during the pandemic was that using online learning media students' interest in learning would decrease. From the results of a survey using a questionnaire on google form for high school students, $18.8 \%$ agreed to use online learning media and $52.75 \%$ disagreed with using online learning media. Student interest in learning increases when online learning is carried out in the classroom. During the pandemic, educators or teachers should be more creative in doing online learning at home so that students don not feel bored and excited while learning distance. So that student interest in learning can increase. Another research conducted by (Widiyono, 2020) states that the majority of students of the PGSD FTIK Unisnu Jepara Study Program take online lectures at home using gadgets (cellphones) with data connections in a fairly good internet signal condition. Online lectures provide an overview of the less than optimal understanding of the material and the number of assignments given to students, resulting in an ineffective lecture process. Contrary to the statement from (Handarini \& Wulandari, 2020) states that online learning conducted at each homemade students is more independent and created motivation to learn. In addition, online learning has become one of the successes in creating social distancing behavior so as to minimize the emergence of crowds that are considered to have the potential to further spread covid 19 in the school environment. This statement is in line with research conducted by (Subakthiasih \& Putri, 2020) which states that the student still had the higher intrinsic motivation than extrinsic motivation in learning English during the Covid-19 Pandemic. In other words, the motivation to learn English that comes from inside students was higher than the motivation comes from outside students.

Motivation is the important role to have successfully education. Motivation should grow from both teacher and students. They have to make online learning in interesting design. One types of motivation in learning languages is Instrumental Motivation. Learners with instrumental motivation acquire English for concrete and practical purposes whereas, integratively motivated learners want to be closer to native speakers. Certain recommendations are proposed to motivate students to learn English (Rozmatovna, 2020). In line with the result by (Hong \& Ganapathy, 2017) stated that Instrumental motivation is found to have a greater impact on students' English language learning. This research also highlights that vocabulary and grammar are the biggest areas of problems that are encountered by students during their ESL learning process, which further influence their speaking and writing skills. Other result in found that the students had high level of motivation-both integrative and instrumental for learning English, but their instrumental motivation was 
slightly surpassed their integrative one (Al-Ta'ani, 2018). Several studies have examined the trend towards instrumental motivation in the language learning process. However, it is rare among those who research in depth about the reasons underlying this instrumental motivation to have an influence on online learning. This recent study analyzes three aspects of instrumental motivation. This is recent study that can be seen from students for academic reasons, personal reasons and social reasons which become the benchmarks for student motivation. This reason can be revealed by calculating the mean score by distributing questionnaires to students.

Online learning that is attempted by all educators in Indonesia has the main goal of being able to transfer knowledge to students so as they can get a best education even during the Covid-19 pandemic. The Covid-19 pandemic is not over yet, but the enthusiasm for learning must be improved. There have been many previous studies on how students respond to receiving online learning. The success of learning for each individual is closely related to two things; the existence of consistent motivation from educators and students. In other words, motivation is a psychological or social need that supports everyone in achieving their important goals in life and after achieving all the things they want, they will be satisfied. A teacher has an important role in fostering this motivation from their students. So that failure in every lesson can be minimized. The discussion in this study is a reflection of some of the success of teachers in fostering student motivation through instrumental motivation even in conditions of the Covid-19 pandemic. The urgency of this research is to determine the highest motivation of students in participating during online learning. By knowing student's reasons for taking online learning, we can analyse student needs in designing online learning at the next meeting. Remembering that, online learning activities are not easy to do if there is a lack of motivation from students.

\section{Method}

Instrumental motivation is instrumental motivation suggests and implies that a learner learns the language in support of a purpose relating to occupation or further useful motives. English is a subject that has four skills in competency such as; listening, speaking, reading and writing. Therefore, online competence can be implemented properly. The data sources chosen several students that carried out online learning at the Faculty of Foreign Languages, Mahasaraswati Denpasar University. Random sampling was effectively used in collecting the data therefore data source has taken by observation, interviews, recording and note taking. Distribution of questionnaires was also carried out to strengthen data analysis. Data is analysed based on the formulation of the problem 
and the study of theory, then analyzed in quantitative and qualitative description. The results from collecting questionnaires can present the level of student motivation in carrying out online learning during the Covid-19 pandemic. The fifth semester students of Faculty of Foreign Languages, Mahasaraswati Denpasar was selected as the population. The total students are 200 and the sample used in this study was 90 participants. Sample data using statistical techniques in accordance with the objectives of this study.

The random sampling was used in this study. The questionnaire was used as an instrument in this study. The questionnaire consists of 12 questions as a test of instrumental motivation which is divided into three different types of questions; academic motivation, personal motivation and social motivation. The responses obtained from the participants were classified into five categories according to Gardner's Attitude and Motivation (Jefiza, 2017), such as strongly agree, agree, doubt, disagree and strongly disagree. Students are required to answer questions from the questionnaire given based on the Likert Scale Rating adopted from (Salamat et al., 2018) Students get a choice of strongly agree, agree, doubt, disagree and strongly disagree. To obtain accurate data, several procedures will be carried out; preparing the necessary instruments during the test, randomly selected samples by random sampling, questionnaires that have been compiled as data collection instruments. The statistical data calculation technique used is the percentage of the score obtained. The mean in each question is calculated from the questionnaire data obtained. Likert Scale Rating is used to measure the type of student motivation. The scale is used to find out whether or not they agree with the students' answers obtained from the questionnaire distribution.

\section{Tabel 1: Standard of Mean}

\begin{tabular}{|l|l|}
\hline Mean Range & Interpretation \\
\hline $3.68-5.00$ & $\begin{array}{l}\text { High degree of } \\
\text { motivation }\end{array}$ \\
\hline $2.34-3.67$ & $\begin{array}{l}\text { Moderate degree of } \\
\text { motivation }\end{array}$ \\
\hline $1.00-2.33$ & $\begin{array}{l}\text { Low degree of } \\
\text { motivation }\end{array}$ \\
\hline
\end{tabular}

Cited in : (Salamat et al., 2018)

\section{Finding and Discussion}

Everyone has many reasons for consistently learning English during the Covid-19 pandemic or during online learning. Some of them learn due to the coercion of individual conditions or other simple thoughts that make them bored of being in this uncomfortable condition. Instrumental motivated learners want to learn something for a number of reasons. Instrumental motivation is instrumental motivation suggests and implies that a learner learns the language in support of a purpose relating to occupation or further useful motives. (Gardner \& MacIntyre, 1991). 
According to (Sepora, T.M and Sepideh, 2012), motivation is commonly thought of as an inner drive, impulse, emotion, or desire that moves one to a particular action. Motivation was examined as a factor of attitudes divided into two basic types of motivation, such as instrumental and integrative motivation. Instrumental motivation refers to motivation to acquire a language as a means of attaining instrumental goals: furthering a career, reading technical material, and translation. An integrative motivation is employed when a learner wishes to integrate himself within the culture of the second language group, to identify himself with and become a part of that society. From the conclusion of this study is that integrative motivation may indeed be an important for successful language learning and some claim that integrative motivation is absolutely essential for successful second language learning.

\section{Academic Aspect}

The results of the observation data using a questionnaire in determining the level of instrumental motivation in the academic field of students in learning.

Tabel 2: Academic Instrumental Motivation

\begin{tabular}{|l|l|l|l|}
\hline No & $\begin{array}{l}\text { Instrument } \\
\text { al } \\
\text { Motivation }\end{array}$ & $\begin{array}{l}\text { Mea } \\
\mathrm{n}\end{array}$ & $\begin{array}{l}\text { Rating of } \\
\text { Motivation } \\
\text { al } \\
\text { Level }\end{array}$ \\
\hline 1. & $\begin{array}{l}\text { Learning } \\
\text { English }\end{array}$ & 3.90 & High \\
\hline
\end{tabular}

\begin{tabular}{|c|c|c|c|}
\hline & $\begin{array}{l}\text { during } \\
\text { pandemic } \\
\text { covid-19 is } \\
\text { needed to } \\
\text { get a good } \\
\text { score in } \\
\text { each } \\
\text { subject }\end{array}$ & & \\
\hline 2. & $\begin{array}{l}\text { I study in } \\
\text { Online } \\
\text { class to } \\
\text { attend the } \\
\text { full class in } \\
\text { this } \\
\text { semester }\end{array}$ & 3.27 & Moderate \\
\hline 3. & $\begin{array}{l}\text { I want to } \\
\text { pass this } \\
\text { collage on } \\
\text { time }\end{array}$ & 4.68 & High \\
\hline 4. & $\begin{array}{l}\text { Teacher } \\
\text { English } \\
\text { Method is } \\
\text { interesting }\end{array}$ & 2.88 & Moderate \\
\hline \multicolumn{2}{|c|}{ Total } & 3.61 & Moderate \\
\hline
\end{tabular}

Based on the table, it can be seen that the total mean score from the academic aspect is 3.61 . It means that students' instrumental motivation in the academic aspect is in the moderate category. Students' motivation in online learning conducted in class is to finish on time. It is proven by the mean number in the questionnaire displayed in the third question, such as, students learning English even in online conditions because they want to finish on time. The total mean of academic aspect is 3.61 at the moderate level. The mean range obtained from the questionnaire 
issued is in the high category. This proves that most of the students taking online lectures aim to finish time. In the first question, namely Learning English during pandemic covid-19 is needed to get a good score in each subject is at a high level. Which proves that students are motivated to take online classes to get good grades in every lesson. Apart from that, some students were motivated to take online classes for several other reasons, such as to avoid absences records in poor attendance. Online learning in the fourth question lacks sympathy from students, because it is in the smallest order with a moderate level. So it cannot be denied that there needs to be an increase in the quality of teaching lecturers in online learning so that students can be motivated to take online classes.

\section{Personal Aspect}

Personal aspect is motivation based on theirself. This has to do with one's intellectual capacity. This includes the behavior of everyone to get motivation in doing online learning. The following table presents the mean results of personal aspects of instrumental motivation.

Table 3: Personal Instrumental Motivation

\begin{tabular}{|l|l|l|l|}
\hline $\begin{array}{l}\mathrm{N} \\
\text { o. }\end{array}$ & $\begin{array}{l}\text { Instrumenta } \\
\text { Motivation }\end{array}$ & $\begin{array}{l}\text { Mea } \\
\mathrm{n}\end{array}$ & $\begin{array}{l}\text { Rating of } \\
\text { Motivatio } \\
\text { nal } \\
\text { Level }\end{array}$ \\
\hline 1. & $\begin{array}{l}\text { Online } \\
\text { learning } \\
\text { during } \\
\text { pandemic }\end{array}$ & 3.61 & Moderate \\
\hline
\end{tabular}

\begin{tabular}{|l|l|l|l|}
\hline & $\begin{array}{l}\text { covid-19 is } \\
\text { useful in } \\
\text { getting } \\
\text { more } \\
\text { understandi } \\
\text { ng in some } \\
\text { subjects. }\end{array}$ & & \\
\hline 2. & $\begin{array}{l}\text { Online } \\
\text { learning } \\
\text { during } \\
\text { pandemic } \\
\text { covid-19 } \\
\text { can make } \\
\text { me active } \\
\text { and creative }\end{array}$ & 4.07 & High \\
\hline 3. & $\begin{array}{l}\text { I study } \\
\text { English } \\
\text { event in } \\
\text { online } \\
\text { learning } \\
\text { because I } \\
\text { want to } \\
\text { speak } \\
\text { English } \\
\text { fluently. }\end{array}$ & $\begin{array}{l}\text { I High } \\
\text { think if I } \\
\text { learn online } \\
\text { can } \\
\text { improve } \\
\text { my skill }\end{array}$ & High \\
\hline Total & 3.21 & \\
\hline
\end{tabular}

The results of testing the table above using a questionnaire. It can be shown that the data from the four questions given the total mean value of the personal aspect is 3.69, which is at a high level. Based on the table, the highest total mean is in the third question, as I study English event in online learning because I want to speak English fluently is the mean number of 
4.29 which is the highest total mean categorized at high level. From these data it can be concluded that students learn online because they are motivated by the desire to be able to speak English fluently even in online learning. Students have a strong desire to improve their speaking skills. Ordered with a total mean of 4.07 which is the second highest total mean with the question "Online learning during the Covid-19 pandemic can make me active and creative". This proves that students are highly motivated in online learning because of the motivation to learn so that they are able to be active and creative. Beside of two motivations chosen by students, some students tend to choose question one "Online learning during pandemic covid-19 is useful in getting more understanding in some subjects and question two, namely $I$ don't think if I learn online can improve my skills". These two questions were not widely chosen by students with the lowest total mean on personal aspects.

\section{Social Aspect}

Aspects Social aspects are things that include the results of the activities of the relationship of each individual with things around him. The social aspect includes everything that is attached to a person and is able to influence the life of each individual. The following are the social aspects of instrumental motivation.
Table 4: Social Instrumental Motivation

\begin{tabular}{|c|c|c|c|}
\hline $\begin{array}{l}\mathrm{N} \\
\mathrm{O} .\end{array}$ & $\begin{array}{l}\text { Instrumental } \\
\text { Motivation }\end{array}$ & $\begin{array}{l}\text { Mea } \\
\mathrm{n}\end{array}$ & $\begin{array}{l}\text { Rating of } \\
\text { Motivatio } \\
\text { nal } \\
\text { Level }\end{array}$ \\
\hline 1. & $\begin{array}{l}\text { Others will } \\
\text { give me } \\
\text { different } \\
\text { opinion if I } \\
\text { get Online } \\
\text { learning } \\
\text { actively. }\end{array}$ & 3.01 & Moderate \\
\hline 2. & $\begin{array}{l}\text { I joint online } \\
\text { learning } \\
\text { effectively to } \\
\text { teach others } \\
\text { more } \\
\text { knowledge }\end{array}$ & 4.32 & High \\
\hline 3. & $\begin{array}{l}\text { Online } \\
\text { English } \\
\text { Learning can } \\
\text { give me } \\
\text { more value } \\
\text { so as can } \\
\text { keep up } \\
\text { modernizati } \\
\text { on era both } \\
\text { in English } \\
\text { skill and } \\
\text { computeriza } \\
\text { tion }\end{array}$ & 4.64 & High \\
\hline 4. & $\begin{array}{l}\text { I will show } \\
\text { my ability to } \\
\text { others. }\end{array}$ & 3.59 & Moderate \\
\hline \multicolumn{2}{|c|}{ Total } & 3.89 & high \\
\hline
\end{tabular}

The table shows that students' motivation to learn online well in social aspects. The data from the table states that the total mean obtained from the social aspects of 
instrumental motivation is 3.89, which is at a moderate level. The highest total mean is the third question which states that "Online English Learning can give me more value so as to keep up modernization era both in English skills and computerization". Based on the data obtained, students are motivated to take part in online learning because they do not want to be left behind by modernization. Modernization requires everyone to be proficient in computer applications and foreign languages. Online learning can increase student knowledge in using computer applications that may not have been done before. So that the combination of computers and foreign languages will be good in improving one's skills. Second place with the statement "I joint online learning effectively to teach others more knowledge" is able to provide high motivation to students in online learning. The total mean in the second statement is 4.32 which is at a high level. The first statement states that "Others will give me a different opinion if I get Online learning actively" to be a low degree of motivation, with a mean of 3.01 at a moderate level. While the fourth statement about online learning motivation because it can show someone's ability to others gets a small interest from the respondent. Only around 3.59 the mean number was obtained from the fourth statement.

Online learning is a demand for every lecture during the Covid-19 pandemic. Students and lecturers must be consistent in their interactions during online learning. Instrumental motivation is divided into three analyzes in this study, such as academic, personal and social motivation aspect. Based on the results of the questionnaire given, it was stated that, in online learning, students had great motivation for the implementation of online learning. This is known for several reasons obtained from the distribution of questionnaires. Several reasons were obtained from the results of the questionnaire that had been distributed, that students had motivation to learn online so they could graduate on time. This reason is the dominant reason found in the above questionnaire results. Students have a strong fear that if they do not attend lectures according to the predetermined schedule, it will make them failed to graduate on time. Graduation is still the strongest motivation for students to finish their studies immediately. When students complete their studies on time, a sense of satisfaction will grow with the hard work that has been done.

In addition, instrumental motivation can grow when students have a strong desire to communicate fluently in English. By carrying out online learning, students try to understand the learning material well and apply the material provided in the form of verbal communication. Students still have good motivation in improving their skills in communicating English even though they are in online learning conditions. However, this must be in line with the consistency of the teacher in 
providing material to students. Lecturers must be more active and innovative in packaging the material provided as concise as possible but still in accordance with the learning procedure. The role of lecturers in providing material and assignments to students is very important to make the learning more conducive. Conducive learning will foster instrumental motivation for every student. Students will start to get bored if the learning carried out by lecturers is less innovative. On the other hand, students will feel motivated by learning that is carried out online if the lecturer can provide good service to their students.

In the current era of modernization, computer applications and foreign languages are needed by many people. Computer applications can be made during online learning. Many new teachings and learning application methods can be used during online learning. So, indirectly, lecturers and students must be able to apply computers and programs used to carry out learning. This can foster instrumental motivation for students in online learning. In addition to learning about English, which has been the subject of discussion, many students study computer applications to improve their computer skills.

Some of these reasons have been found in the distribution of questionnaires that have been given to the respondent. So that based on the data that has been found, it states that students have high motivation during online learning for several reasons discussed above. Online learning can still be applied to students as long as students and lecturers have good consistency to support each other and understand the difficulties of these conditions with one another.

Seeing this fact, it can be concluded that student motivation in accepting learning is still very high. However, the lack of creativity of lecturers in designing teaching materials has a negative impact on student motivation during online learning. Lecturers and students should work together in carrying out online learning well. So that, the learning objectives can be achieved properly. Learning objectives that are usually carried out offline can be packaged properly to improve all students' language skills. Even during the Covid pandemic, lecturers should not be negligent in carrying out their duties to transfer knowledge to students. Students are also expected to actively learn independently during the online learning process. So that independence will emerge from students to gain new knowledge, techniques and theories in language learning that have never been obtained during offline learning. Online learning can increase the knowledge and different skills of each language learner to be more creative and innovative from both lecturers and students. Of course it will be tough task on the part of teachers and students to keep up with the pandemic conditions that are not over. Several choices of online 
learning methods can be used as an alternative to new learning techniques so that student motivation in learning languages remains high.

\section{Conclusion}

After conducting this research on the instrumental motivation of fifth semester students, Faculty of Foreign Languages, Mahasaraswati Denpasar University, it can be concluded that: Students have strong motivation to do online learning. The effectiveness of analysing Instrumental Motivation wer using three different types of instruments, such as from the academic aspect which stated that students' instrumental motivation in the academic aspect was in the moderate category. The dominantly, student motivation in online learning conducted in class is to finish on time. The total mean of academic aspect is 3.61 at the moderate level. Meanwhile, for the personal aspect, it was found that the value total mean of the personal aspect was 3.69 which was at a high level. Based on the table, the highest total mean is in the third question, namely I study English event in online learning because I want to speak English fluently is the mean number of 4.29 which is the highest total mean categorized at high level. The data from the table states that the total mean obtained from the social aspects of instrumental motivation is 3.89 , which is at a moderate level. The highest total mean is the third question which states that "Online English Learning can give me more value so as to keep up modernization era both in English skills and computerization".

\section{References:}

Al-Ta'ani, M. H. (2018). Integrative and Instrumental Motivations for Learning English as a University Requirement among Undergraduate Students at AlJazeera University/Dubai. International Journal of Learning and Development, 8(4), 89. https://doi.org/10.5296/ijld.v8i4.1 3940

Gardner, R. C., \& MacIntyre, P. D. (1991). Who Says It Isn't Effective? Studies in Second Language Acquisition, 13(1), 5772.

https://doi.org/10.1017/S02722631 00009724

Handarini, O. I., \& Wulandari, S. S. (2020). Pembelajaran Daring Sebagai Upaya Study From Home (SFH) Selama Pandemic Covid 19. Family Practice, 8(3), 496-503.

https://doi.org/https://journal.un esa.ac.id/index.php/jpap

Hong, Y. C., \& Ganapathy, M. (2017). To Investigate ESL Students' Instrumental and Integrative Motivation towards English Language Learning in a Chinese School in Penang: Case Study. English Language Teaching, 10(9), 17.

https://doi.org/10.5539/elt.v10n9 p17

Jefiza, A. (2017). Students' Motivation And Attitudes Toward Learning English in An English Course. Journal of Language Literature and 
Education, XII(12), 2-11.

Maulidina, S., \& Bhakti, Y. B. (2020).

Pengaruh Media Pembelajaran

Online Dalam Pemahaman Dan

Minat Belajar Siswa Pada

Konsep Pelajaran Fisika.

ORBITA: Jurnal Kajian, Inovasi

Dan Aplikasi Pendidikan Fisika,

6(2),

248.

https://doi.org/10.31764/orbita.v6

i2. 2592

Rozmatovna, A. O. (2020). The influence of integrative motivation and instrumental motivation on learning English as a Foreign Language. Journal of Critical Reviews, 7(12), 942-945. https://doi.org/10.31838/jcr.07.12. 164

Salamat, L., Ahmad, G., Bakht, M. I., \& Saifi, I. L. (2018). Effects of ELearning on Students' Academic Learning at University Level. Assian Innovative Journal of Social Sciences \& Humanities (AIJSSH), 2 (2)(April), $1-12$. https://doi.org/10.13140/RG.2.2.1 8234.49609

Sepora, T.M and Sepideh, M. J. (2012). Motivation, Its Types, and Its Impacts in Language Learning. International Journal of Business and Social Science, 3(34), 230-235.

Subakthiasih, P., \& Putri, I. G. A. V. W. (2020). An Analysis of Student's Motivation in Studying English. 4(1), 126-141. https://doi.org/https://doi.org/10. 31539/leea.v4i1.1728 AN

Widiyono, A. (2020). Efektifitas Perkuliahan Daring (Online) pada Mahasiswa PGSD di Saat
Pandemi Covid 19. Jurnal Pendidikan, 8(2), 169-177. https://doi.org/10.36232/pendidik an.v8i2.458 